\title{
Note from the Editor
}

\section{Eloise Meneses}

This is the inaugural issue of the On Knowing

Humanity Journal. The journal is associated with, and has emerged out of, a research project of the same name with a website located here:

http://www.eastern.edu/on-knowing-humanityresearch-center. It is open access and peer reviewed. Registration is necessary to see the articles, but it is free.

The purpose of the journal is to promote the development of a Christian faith-based approach to anthropology. Please see the "Focus and Scope" section, under "About", for a fuller explanation. To achieve this purpose, there are three sections of the journal: full length articles, news and opinions, and book reviews:

1. The full length articles offer an opportunity to make a scholarly case for the ways in which anthropological research might benefit from insights from theology. Articles may be primarily ethnography or theory, but in either case will reflect a Christian theological approach to the subject matter.

2. The news and opinions section allows a more informal style of writing and an opportunity to interact with other readers and authors through the journal. Part of our purpose is to create a network of scholars interested in the project and to put them in touch with one another. We especially invite responses to previously published articles in this section.

3. Book reviews are done of a variety of kinds of books, but always with a view to investigating the subject matter from a Christian faith-based perspective and the possibility of applying a combination of theological and anthropological insights to the issues raised.

The launch of the OKH Journal is the result of combined efforts. Neither the research project nor the journal would have been possible without the support of the John Templeton Foundation. The Foundation has given us two grants over a four-year period, critical advice through the application process, and a great deal of encouragement. We are deeply grateful for their assistance.

Dr. Heewon Chang provided us with the information we needed to develop an open access, peer reviewed, journal on the PKP site, and spent significant time tutoring us and answering questions. Her expertise comes from many years of editing, promoting, and developing The International Journal of Multicultural Education located here: http://ijmejournal.org/index.php/ijme. Dr. Andrea Pampaloni, our assistant editor, set up the journal, researched countless matters related to structure and style, designed the layout for the articles, and assisted me with proofreading, editing, and communicating with authors. I thank her most sincerely!

Finally, our deep appreciation extends to our reviewers, who spent significant time in reading through and critically evaluating our journal's submissions. Many of their carefully crafted comments are incorporated in the texts of the articles included here.

The OKH Journal is published twice per year, in January and July. We invite authors to submit articles, news, opinions, and book reviews at any time. Emails to the editor are welcome at emeneses@eastern.edu. 